\section{FORMAS Y CONTENIDOS. EVOLUCIÓN DEL LENGUAJE Y DE LOS ARGUMENTOS EN LA HISTORIETA ESPAÑOLA}

\author{
Jesús Jiménez Varea \\ Prof. Dr. en el Departamento de Comunicación Audiovisual, \\ Publicidad y Literatura, Universidad de Sevilla
}

\section{FORMS AND CONTENTS. THE EVOLUTION OF BOTH THE LANGUAGE AND THE PLOTS IN THE SPANISH CARTOONS}

\begin{abstract}
The following article attempts to put forward the premise for an organized study of the development of the medium of comics in Spain, attending both its formal aspects and its contents. To start with, it establishes the need to impose some kind of logical structuring principle(s) over the intrinsic diachronicity of history, so that a web of genealogical connections can emerge from the otherwise purely empirical enumeration of historical events. Next, the classic distinction between form and content is further articulated into a model which distinguishes substance vs. form in three different planes: content, abstract expression and physical expression. Additionally, the superposition of an increasing multiplicity of visual codes is proposed as the transhistorically essential goal of the formal language (form of the abstract expression) of comics. At last, these theoretical reflections are applied to the conformation of the medium in Spain, with special focus on the first seven decades of its history, insofar as they are considered the fundamental period of its gestation, either formally or thematically.
\end{abstract}

KEY WORDS: Comics; content; expression; history; narratology; structuralism.

Con sus altos y sus bajos, con sus muchas fatigas y algunas alegrías, errores y aciertos, la historia de la historieta española es rica, poseedora de la clase de riqueza que tiene mucho que ofrecer a quienes se acerquen a su investigación desde una variedad de perspectivas. Y tanto es así que basta leer el título del presente artículo para hacerse una idea de lo difícil que sería agotar el objeto de estudio, por falta de espacio, de tiempo, de capacidad analítica, de lecturas, de datos minuciosos para trazar detenidamente la intrincada red de influencias y transformaciones, unas productivas y otras truncadas, que habría de constituir el mapa de la evolución del lenguaje y de los argumentos de la historieta española desde sus orígenes hasta la actualidad. Afortunadamente, no es ese mi propósito, pues no me he planteado hacer una crónica de las pruebas y errores en distintos ámbitos, de cada
RESUMEN: El siguiente artículo trata de plantear la premisa para un estudio organizado del desarrollo del medio de la historieta en España, atendiendo tanto a sus aspectos formales como a sus contenidos. En primer lugar se establece la necesidad de imponer algún tipo de principio(s) que dote(n) de estructura lógica a la diacronicidad inherente de la historia, de tal modo que emerja una red de conexiones genealógicas de lo que, de otro modo, sería la enumeración puramente empírica de sucesos históricos. A continuación, la distinción clásica entre forma y contenido en un modelo se articula en un modelo que distingue sustancia vs. forma en tres planos diferentes: contenido, expresión abstracta y expresión física. Además, se propone la superposición de una creciente multiplicidad de códigos visuales como la meta transhistóricamente esencial del lenguaje formal (forma de la expresión abstracta) de la historieta. Finalmente, estas reflexiones teóricas se aplican a la conformación del medio en España, con especial atención a las siete primeras décadas de su historia, en tanto son consideradas el periodo fundamental de su gestación, tanto formal como temática.

PALABRAS CLAVE: Contenido; estructuralismo; expresión; historia; historieta, narratología.

variación estilística y de cada nuevo giro argumental, de cada nuevo rasgo de un personaje, de cada autor que se hace eco de una corriente de éxito ni de cada ensayo de formato editorial. En su lugar, las páginas siguientes constituyen más bien un esbozo de proyecto para lo que tal vez podría ser un estudio razonable y organizado de la historia de la historieta española con la atención centrada en su lenguaje y sus contenidos, pero sin desatender las condiciones de contorno que actúan decisivamente sobre sus ejercicios particulares.

Por razones de espacio y por la importancia que entrañan esas décadas como periodo de gestación, he preferido centrarme en el tramo histórico que culmina con una cierta normalización del lenguaje de la historieta española a mediados de los años treinta. 


\section{LA HISTORIA DE LA HISTORIETA ESPAÑOLA: ALGUNAS CONSIDERACIONES SOBRE SU ESTUDIO}

Cabe empezar por reflexionar sobre qué hacer cuando se trata de acometer un objeto de estudio complejo desde una perspectiva histórica y circunscrito por cotas de espacio y tiempo tan amplias que abarcan todo un país y alcanzan el siglo y medio, sin contar las conexiones de diversa índole que trascienden tanto el lugar como el periodo señalados. En tales circunstancias, se hace necesario adoptar una óptica macrohistórica, imprescindible si aspiramos a embutir un recorrido tan largo en una veintena de páginas y muy aconsejable si se desea dotar de un sentido profundo y organizador a una historia susceptible de desarrollarse con la extensión que requiera sin caer en la enumeración de datos sucesivos propia de una crónica puramente empírica. Se trata, pues, de establecer un principio axial, ordenador y dador de sentido a la historia, que frente a la diacronía de los acontecimientos se presente como una estructura sincrónica a modo de una gramática cultural. Así, por ejemplo, Antonio Martín, referencia imprescindible en este terreno, encuentra uno de tales ejes organizadores del discurso histórico en la integración de texto e imagen dentro del espacio de la viñeta, fundamentalmente a través de la utilización del bocadillo, lo que, en combinación con otras características que se consideran de algún modo definitorias del sistema expresivo de la historieta, actúa a modo de vector indicador de los avances y retrocesos en la evolución de los lenguajes dentro de su Historia del cómic español: 1875-1939: “Así, una historia del cómic español será en realidad la historia del progresivo perfeccionamiento de su lenguaje expresivo [...]" (1978: 11)1.

Esta clase de planteamiento distingue la labor del historiador de la del mero anotador de hitos, enfrascado en lo que no es sino una cacería ociosa, en tanto sus descubrimientos no se pongan en relación con otros para deseablemente formar parte de un orden mayor. Así, desde el punto de vista de su importancia en la evolución del medio y a falta de una interconexión, podemos reducir a un carácter anecdótico los hallazgos aislados que hacen cada vez más temprana la aparición primera de algo razonablemente asimilable a una historieta española. En el momento de escribir este texto, dicho acontecimiento está localizado en 1859 (Barrero, 2004), pero sin que aún haya evidencia alguna para soportar la repercusión de esa historieta en el desarrollo sostenido del lenguaje o cualesquiera otros aspectos relativos al medio en España. M ientras no se tracen nexos entre ellos siguiendo alguna lógica superpuesta a la cronología, los datos históricos suman tan solo una constelación de acontecimientos, necesaria como producto del trabajo de campo desde luego, pero no constituyentes en sí mismos de un auténtico saber histórico, resultado del procesamiento inteligente de aquellos. De nuevo, hallamos en la obra de Martín ejemplo de esta distinción cuando señala las que fueron durante algún tiempo consideradas primeras historietas españolas, halladas por él mismo ${ }^{2}$, pero establece claramente el comienzo en propiedad de la historieta española en los trabajos de Apeles Mestres y Mecáchis: "Ellos son los que abren la puerta al uso común y a la edición regular de la historieta, ellos la dotan de gran parte de sus recursos expresivos, y prácticamente la 'inventan' en toda su modernidad en España" (2000b: 14).

De este modo se establece la necesidad de abordar la historia de un fenómeno cultural, como lo es la historieta en España, a partir de unos presupuestos teóricos que vertebren la masa amorfa del empirismo en bruto. Una de las opciones más habituales a la hora de abordar la Historia ha sido hacerlo desde una perspectiva teleológica que proyecte los acontecimientos con un cierto orden hacia la consecución de una meta que se sitúa en el horizonte del presente, o tal vez del futuro, del historiador. En el caso concreto del estudio de la historia del cómic, ese finalismo se respira con frecuencia en los muchos acercamientos al actual auge, construido o real, de la llamada novela gráfi$c a$, que hacen de esta una especie de meta en la que han madurado y culminado todos los esfuerzos anteriores del medio. Frente a esas posturas, encuentro más razonables los interrogantes con que han cerrado sus volúmenes autores como Altarriba (2000), otra vez Martín ${ }^{3}$ 0, más recientemente, Santiago García, con su augurio machadiano a los autores que pudieren hacer progresar el medio: "Porque el terreno que tienen que descubrir en realidad no existe. Ese terreno son las huellas que dejan mientras caminan en el vacío" (2010: 274). Y en la evolución de la historieta española, como en la de otros fenómenos dinámicos naturales o culturales, han sido muchos los recorridos, ya se tratara de unas pocas pisadas titubeantes 0 de largas travesías, que aparentemente no han conducido a lugar alguno, si se juzgan exclusivamente desde la óptica de su continuidad aparente hasta la actualidad. 
Por ello, entiendo más interesante plantear el estudio de este proceso evolutivo como una suerte de genealogía a través de la cual redescubrir relaciones olvidadas y establecer líneas de conexión entre editoriales, escuelas, corrientes, discursos e iniciativas que, de otra manera, podrían ser tomadas por carentes de parentesco alguno. Este es el modo en que han trabajado, aun sin hacerlo explícito, los autores mencionados más arriba, situando los desarrollos en el ejercicio de la narrativa gráfica más cercanos al momento de sus respectivos estudios como parte de una intrincada red de precedentes, que muchas veces lo son más por afinidad de alguna naturaleza que por una causalidad superficial4.

\section{SUSTANCIA Y FORMA, CONTENIDO Y EXPRESIÓN, LENGUAJE Y OBJETO: ESBOZO DE UN MODELO TEÓRICO}

Considero fundamental basar el estudio de los lenguajes y los contenidos de la historieta española a lo largo de su historia en un modelo estructural que distinga los primeros de los segundos y que, por otra parte, no debería resultar novedoso pues ha sido aplicado a diversos medios, desde la literatura hasta el cine y el propio cómic. Inspirado en la simple distinción forma vs. contenido, convertida en pilar de la semiótica por su análogo saussureano significante vs. significado, el sistema articulado por Hjelmslev (1961: 47-60) a partir de la multiplicación de los niveles de expresión y contenido por los planos de sustancia y forma se presenta como un presupuesto teórico y una plataforma para el análisis mucho más precisos, dando lugar a un modelo cuatripartito5. Obviamente, la expresión despojada de contenido pertenece al mundo de las ideas exclusivamente, pero constituye un presupuesto potente a la hora de teorizar sobre un medio, pues solo al plano expresivo corresponde en rigor el lenguaje del mismo, entendido como su sistema de significación. Así, si hablamos de un lenguaje aplicado a la narración -numerosas definiciones del medio encuentran imprescindible el carácter narrativo del discurso en el caso del cómic-, los principios de organización correspondientes al punto de vista y la voz deben encontrarse dentro de la forma del contenido, junto con otros como la espacialización y la temporalización, susceptibles todos ellos de ser expresados de distintas maneras según el lenguaje del medio e incluso de diversas maneras a través de un mismo lenguaje. En definitiva, apuesto por asignar el par clásico de historia y discurso - entendido como una manera particular de organizar el modo de contar la historia, pero sin entrar en recursos específicos del lenguaje expresivo- a la sustancia y la forma del contenido, respectivamente. Además, prefiero entender la historia o fábula como ese tipo de constructo mental que David Herman, abanderado de la narratología cognitiva, ha llamado mundo de la historia (storyworld)6. Esta sustancia del contenido que es el mundo de la historia será dada forma a través de una serie de operaciones de revelación, obstrucción, ordenación y filtración de datos sobre ese mundo hasta constituir el discurso, ajeno aún al medio que vaya a expresarlo.

Tal como yo la concibo, la construcción del relato sí se verifica ya al nivel del medio de expresión concreto, si bien estimo necesario introducir una distinción entre la expresión en un sentido abstracto frente a la concreción material de la misma, entendida como el objeto físico real. Asumiendo esta división, sustancia y forma se estratifican en tres planos: contenido, expresión abstracta (lenguaje) y expresión material (objeto). En el caso particular de la historieta, la sustancia de la expresión abstracta sería la imagen fija -con una inmovilidad objetiva, pero no necesariamente estática en cuanto puede albergar dinamismo formal- bidimensional, creada7 y susceptible de ser secuenciada, mientras que la sustancia de la expresión material vendría dada por los elementos constructivos empleados para hacer física su contrapartida abstracta, esto es, tinta sobre papel -imagen producida por adición-en la acepción tradicional del cómic, o bien, si hablamos de cómic sobre un soporte digital, los píxeles de una pantalla radiante o los gránulos de tinta electrónica en un e-book. Podría incluso matizarse en la sustancia del objeto si se trata de una imagen única 0 de una múltiple, resultado de la reproducción aproximadamente idéntica a partir de una misma matriz, caracterizando así la clase de agencia tecnológica que realmente puede hacer que un medio sea potencialmente masivo, lo que numerosos teóricos exigen al cómic para que sea tal, como fruto de la nueva era de la imagen que se gesta entre los siglos XV y XVIII a partir de la combinación de la imprenta de tipos móviles con diversas técnicas de grabad08. En ese doble paso del original a la matriz y de ahí al ejemplar que llegará al lector, es importante observar cómo los sucesivos avances tecnológicos de la reproducción han hecho posible partir de originales creados por técnicas artísticas cada vez más diversas y con mayor fidelidad del resultado final. 
En cuanto a la forma, la de la expresión abstracta correspondería al ejercicio particular del lenguaje de la historieta, concebido como cada uso de lo que podría llamarse, con una intención más figurada que rigurosa, el léxico de la historieta: los diversos modos de significación visual -icónicos, simbólicos, normalizados-que pueden integrarse en el cómic como texto. La articulación de los mismos, todavía dentro de la forma de la expresión abstracta implica una gama de operaciones que guardan una fuerte interrelación en la realidad, pero pueden descomponerse a efectos teóricos, como han hecho R. C. Harvey o Scott M cCloud9. Se hayan elaborado con fines analíticos o como protocolos de creación, ambos modelos explicitan de algún modo lo que, de nuevo figuradamente, sería la sintaxis de la historieta y sobre la que cabría extenderse mucho más en otra ocasión. Interesa también reparar en que la forma de la expresión abstracta de una historieta particular sería una parole respecto a la langue del cómic, por expresarlo en los términos estructuralistas heredados de Saussure. Al desposeerla de su concreción física, podría entenderse como una suerte de descripción total o de guión técnico ideal, imposible de ser trascrito ni ejecutado respectivamente por guionistas 0 artista reales algunos. Ese guión total encerraría toda la información sobre una historieta que tuviese que ver exclusivamente con lo expresivo, desprovisto de contenidos, incluyendo la relativa a la técnica y al tipo gráfico del dibujante, que quedaría reducido en este plano de las ideas a un mero instrumento de plasmación del concepto de ese guionista implícito. Esta noción del guión ideal o total serviría para calibrar sobre las colaboraciones reales de equipos creativos el grado de control ejercido por el guionista empírico según se encontrase más o menos cercano a esa figura de guionista ideal. Insisto en que se trata tan solo de una noción teórica, existente también en los casos en que no hay un quionista real pues el dibujante desempeña también esa función ${ }^{10}$ o incluso cuando el historietista avanza improvisando la historieta sin atenerse a un guión previo ${ }^{11}$. Incluso entonces, la historieta encerraría ese guión intrínseco que no es sino la organización estructural del modo en que ha sido expresada.

La forma de la expresión material abarca todo aquello que tiene que ver con la configuración del objeto concreto que permite al lector consumir la historieta. Estaríamos hablando, pues, del formato en cuanto a sus propiedades espaciales -sus dimensiones, proporciones y otras-, así como a las características temporales de acuerdo con las cuales ha sido diseñada su publicación: singular o periódica, y, de encontrarse en este segundo caso, con una determinada cadencia. El desarrollo de este apartado da pie a discutir todos los tipos de vehículos susceptibles de albergar historietas, desde las revistas satíricas o los suplementos de diarios hasta las novelas gráficas y los webcomics u otras historietas sobre soporte digital -para quienes los consideramos parte del cómic, dado que su lenguaje es el mismo- pasando por los cuadernos de aventuras, los álbumes o los tebeos de contenido variado. Asimismo, habría que tener en cuenta dentro de la forma de la expresión material las relaciones que se establecen entre las propias historietas y los diversos elementos contextuales y paratextuales que lo acompañan como parte de las publicaciones: otras historietas, secciones de diversa naturaleza, cubiertas, diseño de la maqueta...

Por último, resta mencionar el peso de las condiciones ambientales en que se gesta la manifestación del modelo anterior, de tal modo que, si bien los niveles de este han sido establecidas como teóricamente independientes entre sí, las influencias de la tradición histórica, de la legislación, de las culturas o de la lógica de la industria editorial en que se insertan hacen que se generen asociaciones entre ciertos contenidos y ciertas formas. Sobre todo, es interesante tener en cuenta el factor ambiente a la hora de abordar el estudio del nivel del contenido, ya que al ser por definición inespecífico del sistema de expresión -y por tanto del medio del que se está hablando- a él se debe atribuir la concentración de la historieta, en determinados temas, tipos de personajes y estructuras narrativas. Tampoco es en absoluto despreciable el papel determinante de estas presiones externas sobre el desarrollo de los aspectos expresivos, tanto en lo abstracto -por ejemplo, el perfeccionamiento de ciertas estrategias y recursos convencionales- como en lo material -por ejemplo, la herencia de ciertos formatos y su evolución, desechando unos e incorporando otros-. La exposición de estos elementos ambientales tal como se dan y afectan a la configuración del medio en el caso español corresponde ya al propio estudio histórico de la historieta.

\section{EVOLUCIÓN DE LA EXPRESIÓN Y LOS CONTENIDOS EN LA HISTORIETA ESPAÑOLA}

De acuerdo con lo expuesto más arriba, la esencia del lenguaje del medio se encuentra en la suma de la sustancia y la forma de su expresión abstracta, y de su exploración 
debería poder surgir alguna definición satisfactoria del medio. No es mi propósito aportarla aquí, pues más que marcar los límites que excluyen a lo que no es historieta, prefiero establecer en qué sí consiste el lenguaje de la historieta: como sistema expresivo, la historieta es un texto visual constituido exclusivamente sobre el espacio bidimensional fijo, pero con el potencial de usar todas las herramientas significativas que este puede alojar -secuenciación, abstracción, figuración, convenciones generales y específicas, etc.- para actuar como interfase capaz de hacer que el lector evoque en alguna medida un mundo de la historia (o un modelo mental genérico si renunciamos a la narratividad) tanto en sus propiedades visuales inmutables y planas (afines a las de su espacio físico de representación) como en las que no lo son (profundidad y volumen, tiempo y movimiento, sonido y demás percepciones correspondientes a los otros sentidos, emociones, pensamientos, atmósferas...). Como tantos intentos de definir el medio en el pasado, mi formulación puede resultar demasiado amplia como para lograr el cometido de una definición, por lo que, de entrada, ni siquiera la propongo como tal12. Sin embargo, en lo que llega a abarcar, me resulta útil para apoyar lo que considero la aspiración ontológica de la historieta: la máxima integración de todos esos distintos tipos de signos y sistemas de significación que pueden operar sobre la superficie de representación; y por integración me refiero al acercamiento espacial de los distintos signos hasta el punto de que unas mismas partes de la imagen puedan significar de varios modos a la vez. El grado de integración de los diversos modos de significación implicados en este sistema actuará como un vector de la evolución del lenguaje de la historieta.

Una parte de mi inspiración para el párrafo anterior se encuentra en el texto de André Bazin "Ontologie de l'image photographique"13, donde este pensador de la fotografía y el cine ubicaba estos sistemas de producción de imágenes en la culminación de una querencia humana por preservar su existencia efímera de la muerte que se remontaría hasta la práctica egipcia de embalsamamiento de los difuntos. No comparto con Bazin la trascendencia cuasireligiosa -o directamente religiosa- de sus reflexiones ni me encuentro próximo a su aparente convicción en la objetividad de la lente fotográfica, pero me parece oportuna su siguiente afirmación: "La photographie, en achevant le baroque, a libéré les arts plastiques de leur obsession de la resemblance. Car la peinture s'efforçait au fond en vain de nous faire illusion et cette illusion suffisait à l'art, tandis que la photographie et le cinéma sont des découvertes qui satisfont définitivement et dans son essence même l'obsession du réalisme" (1990: 12). Ya fuera casual o causalmente, lo cierto es que el invento fotográfico coincidió con el segundo punto de inflexión en la evolución iconoclasta descrita por el filósofo Jean-J oseph Goux:

[...] un proceso continuo y progresivo. Estas rupturas han acarreado cambios en la actitud del sujeto que contempla las obras: se pasó sucesivamente del sujeto frontal al sujeto focal, y luego al sujeto operativo. En la primera ruptura (del frontal al focal) está marcada por la aparición de la perspectiva, y la segunda (del focal al operativo) por la del arte abstracto [...] las formas 'libres' del arte abstracto permiten un juego indefinido de combinaciones que le confieren una productividad inédita, de ahí la noción de sujeto operativo (Groupe İ, 1993: 20).

Este fenómeno que, desde distintas perspectivas teóricas ha sido percibido como una liberación de las artes plásticas de una hipotética obligación de reproducir la realidad, tuvo lugar bien entrado lo que Valeriano Bozal ha llamado "el siglo de los caricaturistas" (1989). En opinión de este historiador del arte, los practicantes de la caricatura fueron unos avanzados en la emancipación de los dictados de la tradición artística imperante que equivocadamente pretendía crear una versión mejorada de la realidad:

Los teóricos del clasicismo barroco siempre consideraron que la empírica era una realidad deforme y que la tarea de los artistas consistía precisamente en mejorarla, en sus imágenes, eliminando deformidades e imperfecciones. De otro modo: lo real percibido por los sentidos era deforme, caricaturesco, cómico. Mas ese real percibido por los sentidos es el tema de estamperos e ilustradores gráficos, caricaturescos 0 no. Desde aquel punto de vista [...] todas estas imágenes son caricaturas (Bozal, 1989: 14).

Impulsados por la agilidad que confería la innovación litográfica aportada por Alois Senefelder, los caricaturistas pusieron a punto unos recursos gráficos en los que la expresividad se anteponía a la iconicidad y la distorsión se prestaba a la codificación de significados culturales, todo lo cual nutriría en unas décadas a los historietistas que estaban por llegar. No solo nacería la historieta libre de replicar analógicamente la realidad, tarea que recaería en la imagen fotográfica, sino también de devolverla embellecida, una 
vez puesto en cuestión el marco sociocultural que había servido de premisa al barroco. De este modo, el repertorio de lo que habría de ser la forma de la expresión historietística comenzaría a gestarse como consecuencia de unos cambios culturales que se reflejaron en otros medios con los que compartía la sustancia expresiva.

A la hora de describir a grandes rasgos la evolución histórica del lenguaje de la historieta, resulta útil observar cómo se ha abordado dicha tarea en el ámbito de otros medios. Así, tratando la historia de las escrituras fílmicas, Noël Burch propone la noción de un Modo de Representación Primitivo (MRP) anterior al Modo de Representación Institucional (MRI) normalizado por la hegemonía de la cinematografía hollywoodense y que había dado en considerarse la manera natural de hacer cine. Burch critica esta concepción que sitúa al cine en una trayectoria hacia la reproducción fidedigna de la realidad de evidente parentesco con los pensamientos de Bazin: "A lo largo del siglo XIX, asistimos a la 'apertura' por etapas muy distintas [...] de una gran aspiración que viene a ser la portadora de la ideología burguesa de la representación [...] la Re-creación de la Realidad [...] la realización de una ilusión perfecta del mundo perceptual" (1991: 21). Mientras que el lenguaje de la historieta, de acuerdo con la caracterización de que la doté antes, aspira a expresar una realidad -no la realidad - en todas sus propiedades por medio solo del espacio bidimensional fijo, en cambio el cine se plantea como un medio progresivamente acaparador en su afán de llegar al mismo punto14. Pese a sus diferencias y enfatizando la entidad propia del lenguaje de la historieta respecto al cinematográfico -entre las cuales ha habido un rico flujo de préstamos culturales, expresivos y temáticos en ambos sentidos- no se puede dejar de reparar en los paralelismos, incluso temporales, entre la evolución de ambos hacia sus propias versiones de un MRI. Para el medio que le ocupa, Burch se centra en los casos de tres países, Estados Unidos, Reino Unido y Francia, y observa cómo hasta aproximadamente 1912 su cinematografía se basa en un lenguaje que deja al espectador "fuera" del universo diegético. En los años siguientes, el cine estadounidense inicia un proceso de transformación destinado a sumergir al público en lo que se le está narrando a través de unas ciertas formas de poner en escena, realizar y montar que le hagan viajar por ese mundo de la historia sin moverse de su butaca. Se establece así a cada lado del Atlántico una forma de hacer cine que tiene sus equivalentes en el campo de la historieta y que en ambos medios va a incluir un retroceso progresivo del modelo europeo frente al estadounidense como consecuencia de un fenómeno común de globalización de la cultura del entretenimiento procedente del país norteamericano. Puede decirse que, mediados los años treinta, el cómic español -el europeo en generalestá en camino de establecerse en la versión historietística del MRI propagado por el material estadounidense, que entra masivamente en España a través de las series sindicadas que publican revistas como Yumbo (1934), Aventurero (1935), Mickey (1935), Cine Aventuras (1935) y La Revista de Tim Tyler (1936). Naturalmente, como en tantos otros aspectos de la vida y la cultura españolas, unos factores ambientales de tremenda trascendencia como fueron la guerra civil y la posterior dictadura franquista trastornaron el rumbo previsible, provocando incluso un retorno a modelos anteriores.

De vuelta a los inicios de un MRP historietístico español, la temprana "Por un coracero", de Pellicer, refleja la libertad respecto a la imposición de envolver las figuras en un espacio de referente real: en su lugar, la imagen se limita a representar la figura central, a modo del primitivo sujeto frontal, pero acompañada por los elementos accesorios indispensables para situarla en un marco coherente con la acción que desarrolla; en varias de las viñetas, la estrategia de emplazamiento espacial de la figura se reduce al mínimo indispensable en la forma de un esbozo de sombra que ancla al personaje a los hipotéticos suelo o muro sobre los que se proyecta (véase la reproducción en Martín, 2000b: 30-31)15. Historietas posteriores del mismo Pellicer (imagen 1), de Apeles Mestres, de Mecáchis, de Ramón Cilla o de Ángel Pons, por nombrar a unos pocos pioneros, muestran cómo esta primera medida de desentendimiento de la necesidad de insertar a las figuras en un espacio gráficamente explícito se constituye en norma ya en los primeros años de la historieta corta humorística. Otra muestra de la libertad con que los creadores de las primeras historietas se comienzan a plantear la representación del mundo en sus viñetas la ofrecen ejemplos como "Últimas horas del carnaval" (Granizada, n-2, febrero de 1880; en Martín, 2000b: 42-43). En ella Apeles Mestres somete dicha representación a las impresiones alucinadas que experimenta el ebrio protagonista, abriendo así una vía de comunicación desde la forma de la expresión visual hacia la focalización del relato sobre la psicología de un personaje, que reside en la forma del contenido. Progresando en este sentido, la entrega de "El aguijón de los celos", del 7 de septiembre de 1886 


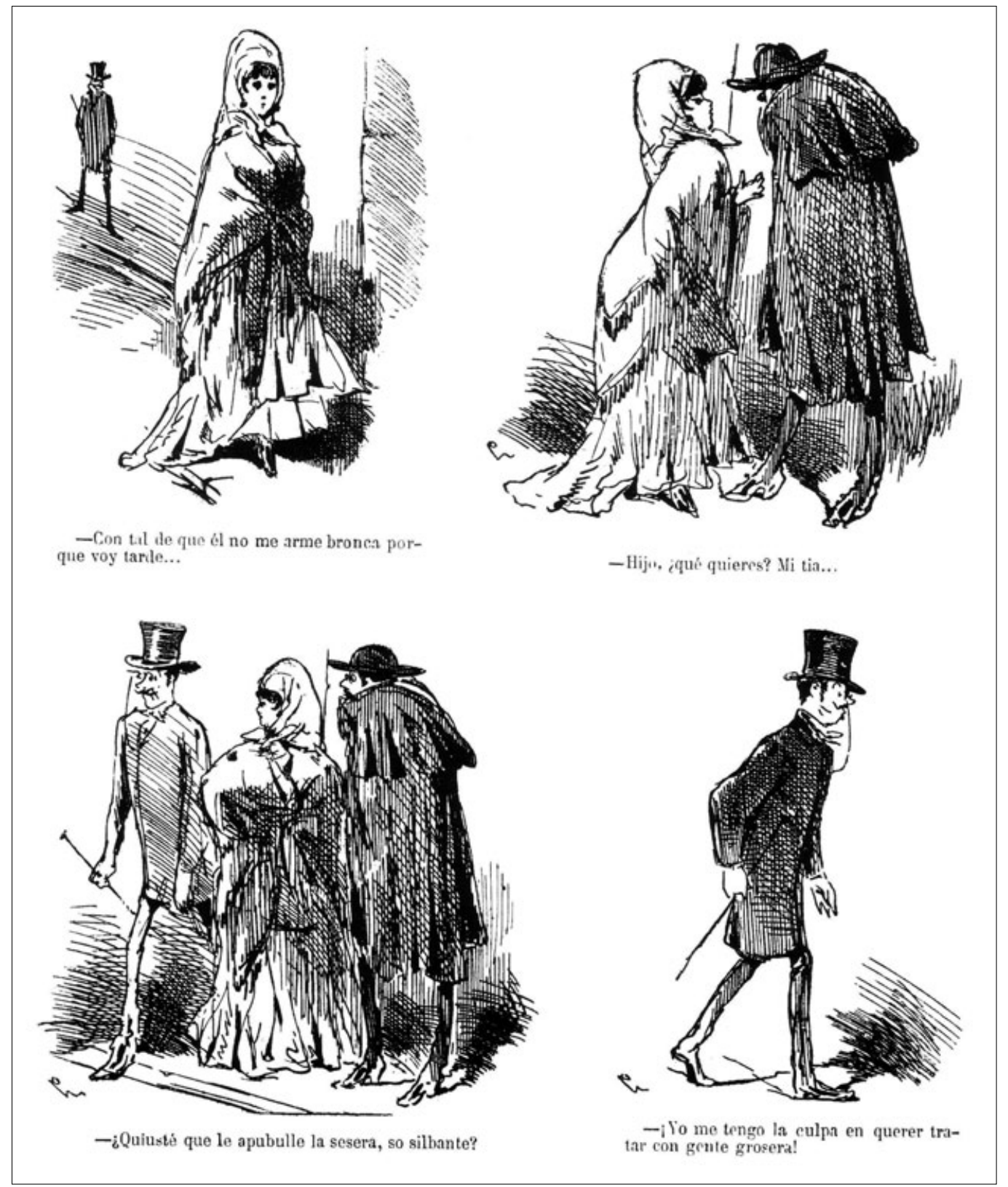

Imagen 1. De "Escenas matritenses", por José Luis Pellicer (El Mundo Cómico, $n^{\circ}$ 24, 13 de abril de 1873; reproducido de Martín, 200ob: 35). Como ya hiciera en "Por un coracero", Pellicer centra la composición de sus viñetas en uno o más sujetos, mientras sugiere el emplazamiento espacial a través de unos pocos indicios visuales.

(La Caricatura, n-87, en Martín, 2000b: 59), constituye todo un catálogo de tentativas de recursos visuales fijos para expresar el movimiento y el estado interior de un personaje. $Y$, por destacar el atrevimiento de algunas de estas experiencias pioneras, con la historieta "Todo lo vence el amor ó Una estocada al marido" (La Semana Cómica, año V, № 14, 17 de abril de 1891; en Martín, 2000b: 68), su autor, Figuer (imagen 2), se adelantó en más de nueve décadas a la estilización 
minimalista de la figuración que caracteriza a la célebre serie El bueno de Cutlass: no solo el fondo en que se inserta la acción se manifiesta nada más que en unas pocas ocasiones con el propósito exclusivo de situar concisamente a los personajes, sino que estos mismos tienen su corporeidad reducida a unos pocos trazos que en poco se diferencian de los rebordes que delimitan los marcos de las viñetas.

Naturalmente, todo el desarrollo del lenguaje y los temas que ha tenido lugar desde entonces permite a la serie de

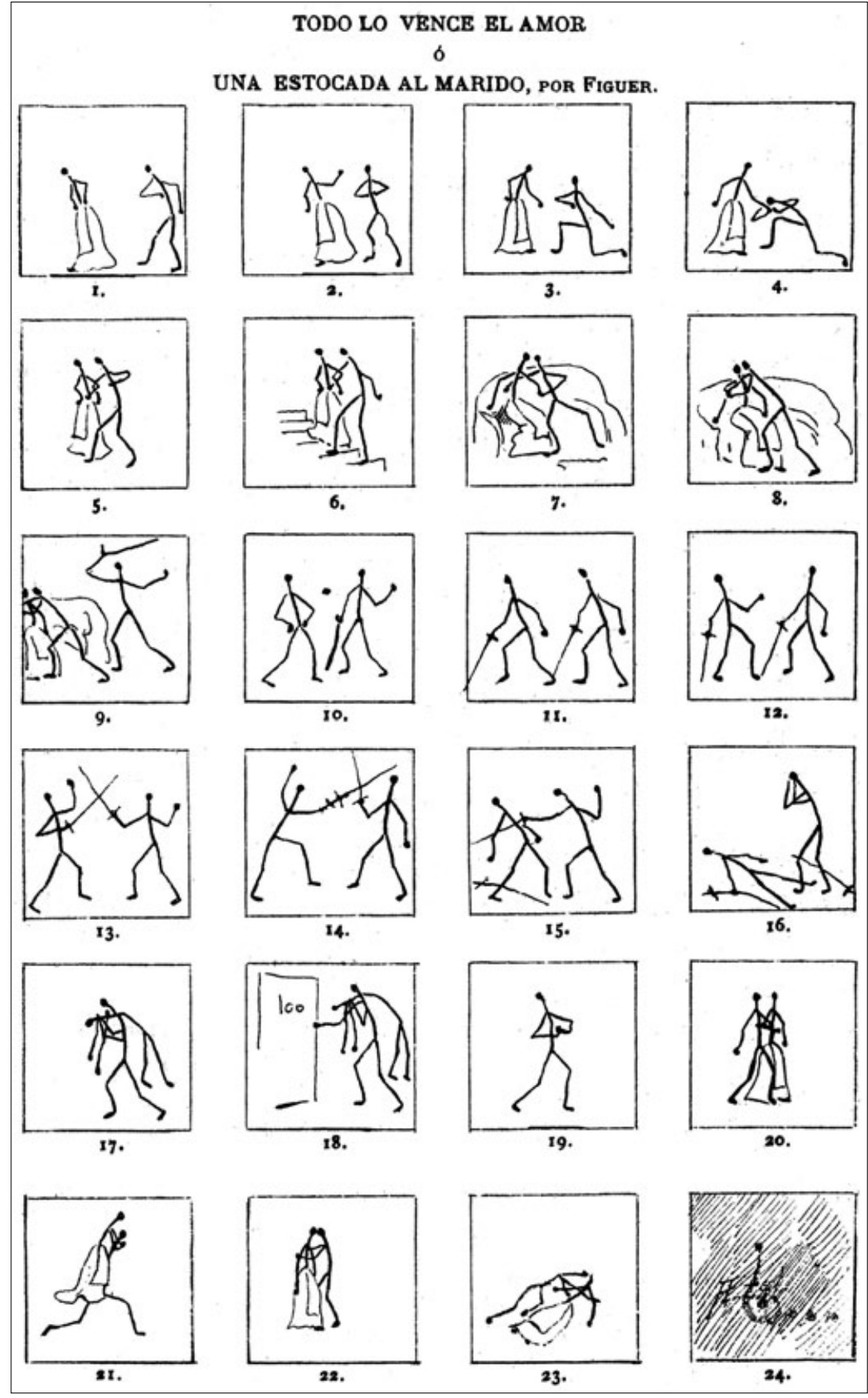

Imagen 2. "Todo lo vence el amor ó Una estocada al marido", por Figuer (La Semana Cómica, año $V, n^{\circ} 14,17$ de abril de 1891; reproducido de Martín, 200ob: 68). El autor crea un temprano ejemplo de minimalismo gráfico consciente, en el que los personajes se reducen a configuraciones elementales, casi carentes de superficie. 
Calpurnio funcionar como un juego constante sobre las convenciones de lenguaje y géneros, gracias en buena medida al propio esquematismo de los personajes: en el contenido, los existentes y los acontecimientos se ven reducidos a componentes elementales, susceptibles de pintorescos malabarismos narrativos; mientras que, desde el punto de vista del lenguaje, la semejanza que guarda el signo ligeramente icónico que es Cutlass con los signos de diversas naturalezas que constituyen el léxico de la historieta pone de manifiesto que comparten la misma sustancia y conduce con naturalidad a los frecuentes juegos de trasgresión de las convenciones expresivas. En este sentido, entre el ejemplo de Figuer y la obra de Calpurnio puede trazarse una línea genealógica que necesariamente ha de pasar por los ejercicios de K-Hito y creadores polifacéticos como Tono y Mihura, anunciando las características del llamado "humor nuevo": "un humor neo-vanguardista [que] se propone, junto a la catarsis cómica, formular un juicio crítico sobre la realidad y el lenguaje tal y como habían sido interpretados por la tradición" (Llera, 2007: 314). En una forma más costumbrista el humorismo descomprometido, en contraste con el pragmatismo ácido de la sátira ${ }^{16}$, también se había encontrado en el propio caldo de cultivo de las primeras historietas españolas:

[...] la prensa satírica desaparece con la Restauración, dando paso a una prensa humorística en la que la caricatura ha perdido el carácter rabiosamente satírico del periodo anterior, y a una prensa general muy ilustrada. Va a ser en esta nueva prensa y para la sociedad de la Restauración donde crecerá y se afianzará la historieta española, alcanzando su verdadera razón de ser (Martín, 2000b: 9).

En el origen del cómic se produce ya, como consecuencia de ese linaje caricaturesco en el que se inscribe, una temprana asociación entre los teóricamente independientes planos de la expresión y el contenido al vincularse la historieta al humor, de cuya variedad gráfica será un apéndice casi en exclusividad durante mucho tiempo. Así ocurre en España, donde las primeras historietas surgen con el propósito de hace reír, en publicaciones periódicas con una importante presencia de humor gráfico, como El Mundo Cómico. En el mismo número de esta publicación que contiene la historieta "Por un coracero", mencionada más arriba, encontramos también la más breve "Al buen pagador...", por Francisco Cubas (Martín, 2000b: 33). Consistente en tan solo tres viñetas, esta historieta da pie a plantearse la posibilidad de que los propios mecanismos intrínsecos del humor forzaran a los autores, con mayor o menor consciencia de ello, a descomponer sus chistes en viñetas para mejorar su eficacia (imagen 3). Junto a las variadas explicaciones del humor que apelan a motivos psicoanalíticos y emocionales, existe un conjunto de modelos de índole cognitiva que se agrupa bajo la denominación de "teorías de la incongruencia", en función de las cuales la comicidad del chiste radica en un cierto desenlace del proceso de resolución de un problema lógico: (1) planteamiento del chiste; (2) predicción del desenlace; (3) desenlace; (4.a) si el desenlace es el previsto no provoca sorpresa ni humor, pero (4.b) si no lo es provoca sorpresa; (4.b.1) si del planteamiento no puede extraerse una regla para el desenlace imprevisto, la sorpresa se traduce en perplejidad, mientras que (4.b.2) si se puede encontrar esa regla, el efecto final es cómico (Suls, 1972). En la citada historieta de Cubas no es difícil localizar la secuencia que conduce de (1) a (4.b.2), haciendo natural su articulación en forma de historieta para, al mismo tiempo que las fases se dosifican al lector, vehicular una parte esencial del minirelato que es este chiste -la pose adoptada por el cliente a la hora de "pagar" su cuenta en el desenlace- a través del dibujo, consiguiendo de esta manera un efecto cómico que no se habría podido lograr tan eficazmente solo por la palabra ni por una combinación de texto escrito y dibujado en una imagen única. En resumen, la estructura de procesado de la información que algunos psicólogos postulan para lo que solemos considerar una sustancia de contenido como es el humor se traduce en una cierta estructura narrativa (forma del contenido) que, a su vez, favorece una cierta forma de la expresión. Y básicamente esta estructura narrativa es la que sigue repitiéndose en los chistes desarrollados en forma de cómic que han poblado la historia de la historieta española, haciendo que en el género de humor haya imperado durante mucho tiempo el relato de muy corta extensión: la tira, la media página, la página completa o la doble página a lo sumo. Se trataría de una confluencia de afinidades entre la propia naturaleza del chiste y la cultura editorial en cuyo seno se gestan estas historietas, que se incorporarán al surtido de secciones habituales de los diarios, las revistas y los tebeos de contenido variado, desde el primigenio Dominguín hasta el actual El Jueves (cuya oferta es en gran medida de historieta), pasando por los fundamentales TBO, Pulgarcito 0 Jaimito. 
El chiste en forma de historieta constituye un ejemplo de relato completo, pues el lector recibe en una sola entrega: presentación, nudo y desenlace, por mínimos que sean. Por dilatación de este esquema -al narrativo me refiero y no al lógico, que está ligado específicamente al resorte del chistela historieta avanza hacia relatos de mayor complejidad que requieren varias páginas para su desarrollo, como las que comenzara a realizar Apeles Mestres en 1878 para sus

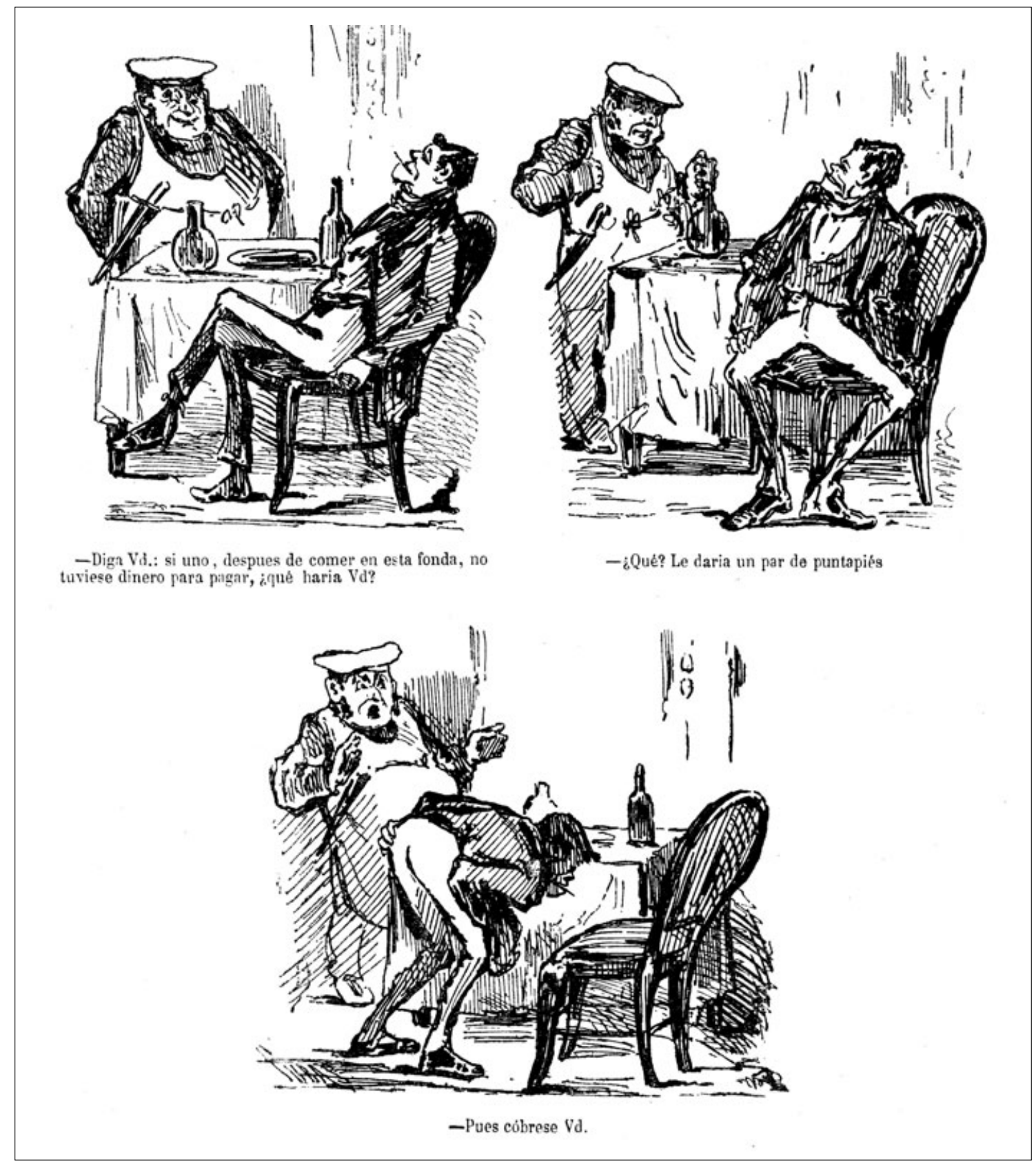

Imagen 3. "Al buen pagador...", por Francisco Cubas (El Mundo Cómico, $n^{\circ}$ 22, 30 de marzo de 1873 ; reproducido de Martín, 200ob: 33). La secuencia de viñetas surge por articulación de los mecanismos fundamentales del chiste. 
"Cuentos Vivos". En este caso, incluso en las historietas que pueden considerarse cómicas, se produce un alejamiento del chiste singular como motivo de unidad de la narración, superados los límites acostumbrados de su extensión, y la sustancia del contenido deriva hacia otras temáticas, a la vez que el incremento de espacio permite sofisticar las formas. Es fácil comprender que los usos y costumbres de la cultura editorial supusieron un freno al aumento del número de páginas de la original historieta autoconclusiva, puesto que para los editores y la mayoría de los propios autores no se trataba más que de una variedad del chiste gráfico. Como tal, su cometido no era acumular el espacio, sino compartirlo con el mayor número posible de congéneres o de materiales de otro tipo, número tras número de la cabecera que los alojase.

Precisamente, el hecho de que las historietas españolas nacieran dentro de publicaciones periódicas hizo posible dos fenómenos que, por separado o en combinación, moldearían profundamente su contenido: por una parte, la reutilización de uno o varios personajes de una historieta autoconclusiva breve de un número en otra de un número posterior; y, en segundo lugar, el aumento del número de páginas del relato por medio de la dosificación del mismo en entregas sucesivas, cada una de ellas de poca extensión, hasta completarlo. La primera estrategia introduce en la cultura de la historieta española la serie episódica y a los personajes fijos que la protagonizan, mientras que la segunda abre las puertas a la serialidad. Una vez más, el linaje de la cultura popular y progresivamente de masas en que se inscribe la historieta explica la adopción de tales tácticas, desarrolladas para otros medios de manera intuitiva tal vez, pero con una eficacia sólidamente fundada en el refuerzo de la identificación del lector con los personajes a causa de su recurrencia17 y en el efecto Zeigarnik provocado por la suspensión del

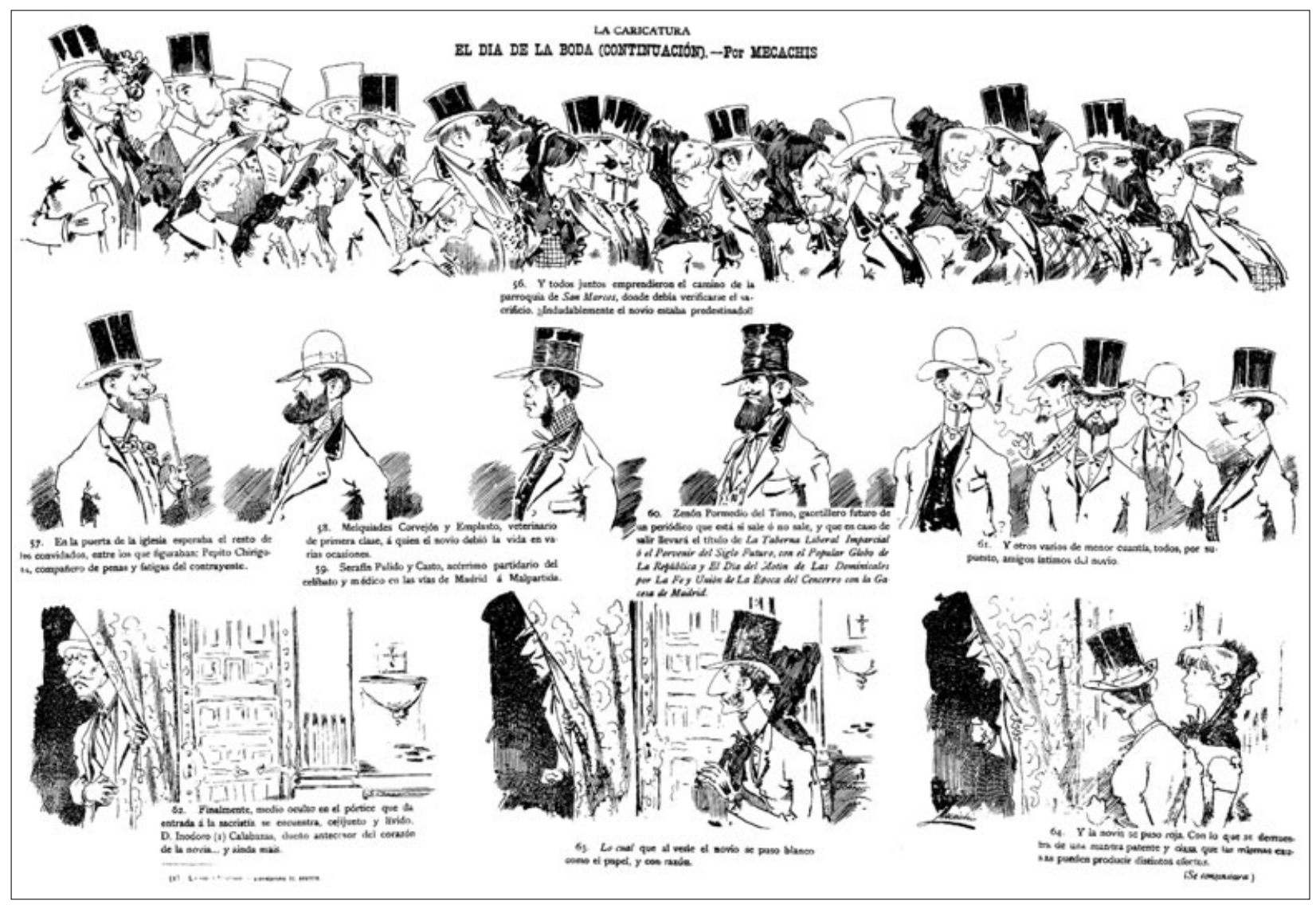

Imagen 4. Una entrega de "El día de la boda", por Mecáchis (La Caricatura, $n^{\circ} 42,11$ de agosto de 1885; reproducido de Martín, 200ob: 52). Aplicada en este caso a una temática costumbrista, la serialidad permitió prolongar los relatos a lo largo de sucesivas dosis de escasa extensión individual. 
relato18. Si bien un ejemplo tan temprano como el serial de M ecáchis "El día de la boda" (La Caricatura, mayo a diciembre de 1885) relata unos hechos absolutamente costumbristas (imagen 4), la serialidad en la historieta demostró su adecuación a las temáticas aventureras a partir de la obra de Xaudaró. Al mismo tiempo, este autor perfeccionó los criterios de elección de momentos significativos para su desglose secuencial, desarrollando una forma de la expresión especialmente adecuada para un tipo de relato cuyos requisitos narrativos de ritmo y velocidad difieren de los del chiste. Pero, sobre todo al principio, el moderno resultado de sus dibujos está lastrado por unos pesados textos descriptivos al pie que no se encuentran en sus historietas breves y a cuyo respecto reflexiona Martín: "Nos queda la duda sobre las causas de este fallo, que puede deberse a una imposición editorial, pero que más bien parece responder a vacilación del autor ante los problemas de guión y planificación que presenta una historia de gran extensión" (Martín, 1978: 35). También en el terreno de la especulación, esta divergencia de las formas expresivas en un mismo autor entre la agilidad del lenguaje aplicado a la historieta corta frente a la presencia de pesados textos en sus narraciones prolongadas de aventuras pone de manifiesto cómo estas sufren la asimilación a modelos de expresión preexistentes para las mismas temáticas (imágenes 5 y 6). Así, si la historieta breve con una fuerte unidad estructural parece surgir por secuenciación del chiste gráfico, la historieta seriada -tal vez desde su origen o quizá más tarde por precipitación dentro de unas categorías culturales conocidas- se concibe a partir del folletín o de la novela por entregas. Progresivamente, el dibujo asumiría mayor responsabilidad en la transmisión del relato, pasando su relación con el texto escrito desde la mera redundancia propia de las ilustraciones de un folletín hasta el relevo, más propio de la integración

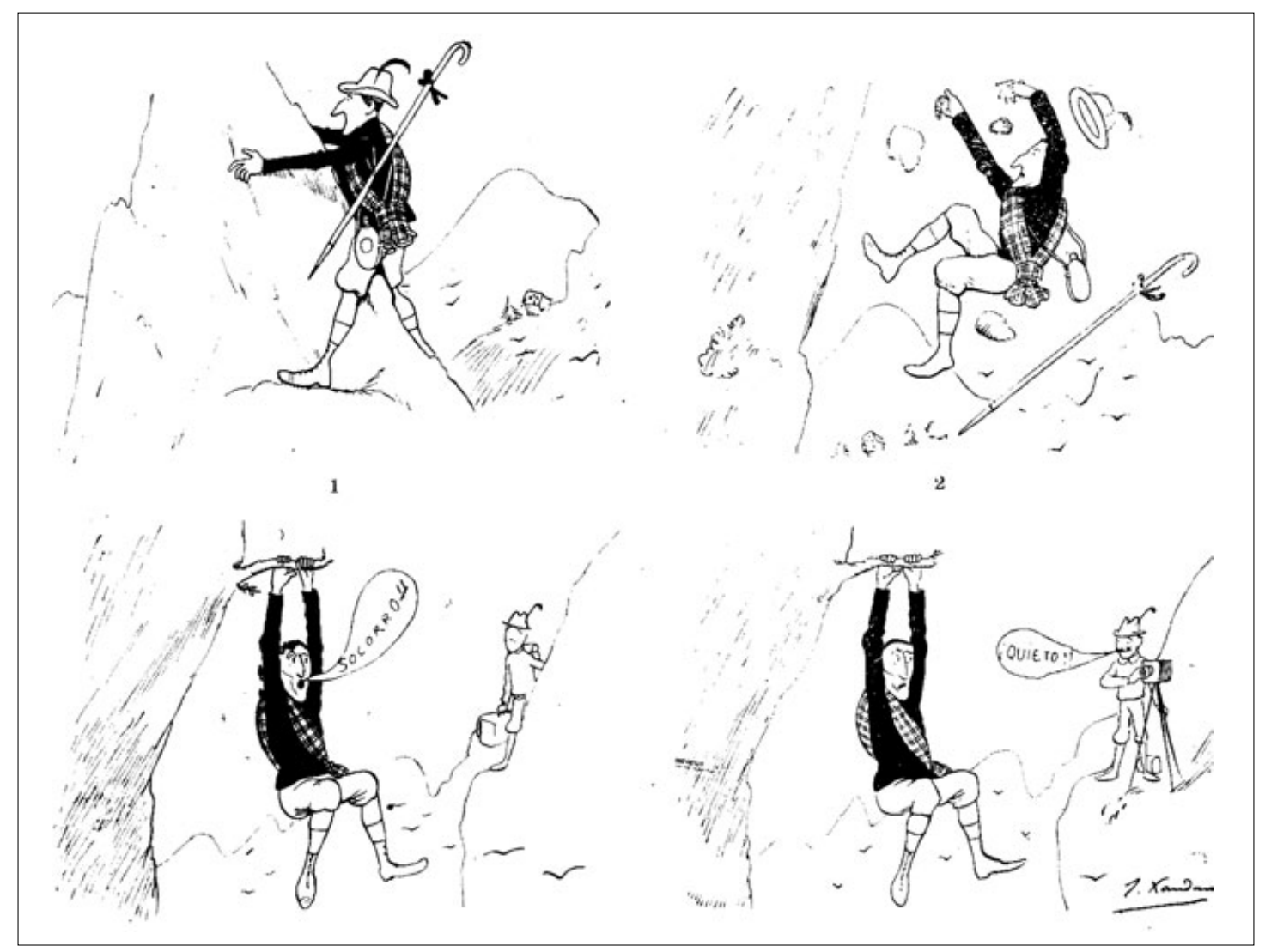

Imagen 5. "El arte a 3.000 metros sobre el nivel del mar", por Joaquín Xaudaró (La Hormiga de Oro, XVII, $n^{\circ}$ 22, 1900; reproducida de Remesar, 1984: 8). Ejemplo de historieta humorística autoconclusiva por Xaudaró, donde la información es vehiculada esencialmente por la representación icónica y cabe destacar el uso de bocadillos, poco habitual en la obra de este autor. 


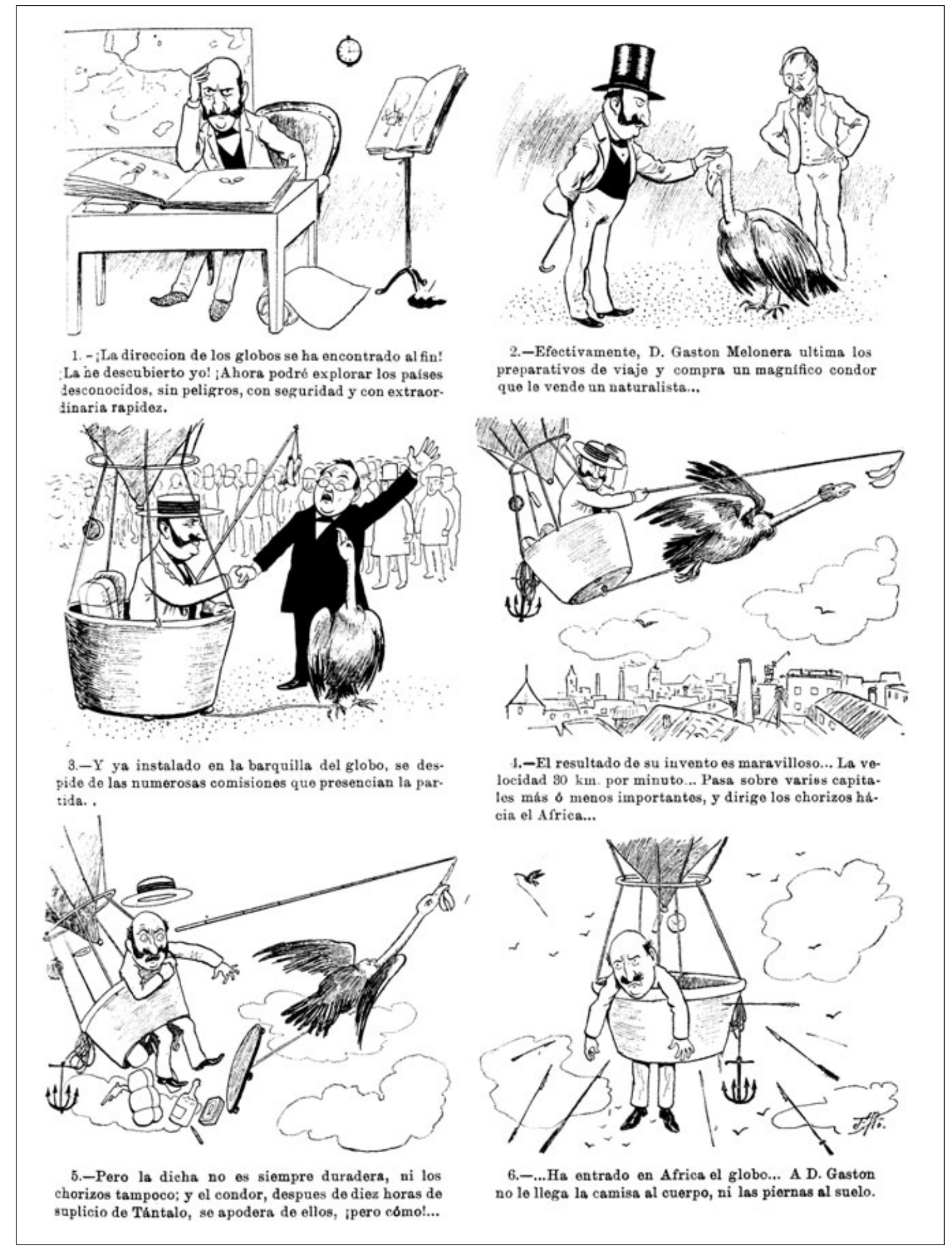

Imagen 6. Primeras viñetas del serial "En busca de países desconocidos", por Xaudaró (publicado en su totalidad en los números 33 a 45 de La Hormiga de Oro, en 1897; reproducido de Remesar, 1984: 9). Frente a la dominancia comunicativa de lo icónico en sus historietas cortas de humor (véase la imagen 5), Xaudaró apoya sus narraciones seriadas de aventuras sobre textos de apoyo de relativa densidad. 
entre texto e imagen en una historieta. Desde esa perspectiva y a efectos de una genealogía de la historieta, se trataría de dos ramas diferentes de la narrativa gráfica que llegarán a converger en un mismo sistema expresivo, pero, hasta entonces, los seriales de aventuras se asemejarán aún durante muchos años a folletines ilustrados. Esta circunstancia, según Antonio Lara, estuvo determinada sobre todo por la escasa valoración de la imagen figurativa respecto del texto escrito dentro de los esquemas culturales europeos: "[...] yo creo que llegó a ser más importante, si cabe, este otro prejuicio cultural de considerar que la imagen era una realidad menos valiosa que el texto y, por consiguiente, para evitar el menosprecio de los cultos se subordinaba o esclavizaba a él necesariamente en la mayoría de los casos" (1996: 36).

Además del serial, Xaudaró fue pionero de la estructura episódica con "Vida y milagros del hijo de Gedeón" (Blanco y Negro, enero a septiembre de 1908), donde cuenta con un personaje fijo que protagoniza en cada entrega un pequeño relato completo. Esta sería -lo era ya a esas alturas en Estados Unidos- una de las fórmulas más explotadas en el cómic mundial, aunque se ha de puntualizar que, en esta variante de Xaudaró, nos encontramos con un protagonista, al menos en la primera fase de la serie, que experimenta el paso del tiempo de una entrega a otra: cada uno de esos episodios recoge alguna ocurrencia desde la niñez hasta la edad adulta del personaje. Si hubiera que buscar en toda la historia de la historieta española un ejemplo del seguimiento de un personaje a lo largo de su vida, tal vez el mejor ejemplo serían las series conectadas por Pablo Gómez, el trasunto autobiográfico de Carlos Giménez, cuyas vivencias testimoniales de la España de varias décadas arrancan con la etapa infantil de "Paracuellos" en la revista Muchas Gracias (1976), avanzan por la adolescencia de "Barrio" y por la juventud adulta de "Los profesionales" y "Rambla arriba... Rambla abajo" hasta la madurez del narrador representado de "Los cuentos del tío Pablo". Al mismo tiempo, el desarrollo de estas series a través de distintos formatos, desde las páginas únicas dentro de revistas antológicas hasta los álbumes, donde escoge también una estructura capitular de pequeñas historias, ofrece un valioso corpus para el estudio de los condicionamientos que imponen los usos editoriales en cada momento y cómo puede responder a ellos un autor -en el caso de Giménez- de indudable talento.
Sin embargo, lo común será que los personajes fijos se mantengan congelados en un presente que se reinicia desde el final de una entrega hasta el principio de la siguiente, manifestando lo que Umberto Eco describiera en referencia al clásico Superman de la era Weisinger como "una trama sin consumo" (1997: 235). Este concepto es especialmente interesante en relación con aquellos personajes que, convertidos en valiosos activos para sus propietarios, han disfrutado de existencias prolongadas en función del rédito que generase su popularidad y a través de periodos históricos con distintas características socioculturales. En tales casos han tenido que transformar muchos de sus elementos narrativos y figurativos para adaptarse a los nuevos tiempos, sin que la llegada de estos afectara a su edad ficcional, pero contando con el conocimiento acumulado por los lectores sobre sus peculiaridades. Muestra de que los personajes fijos son una fórmula editorial de probado éxito es el hecho de que apostase por ella Bruguera, editorial que desde finales de los años cuarenta mostró unos claros planteamientos industriales en la publicación de hsitorietas. Las observaciones de Ramírez respecto a "Don Pío" (J osé Peñarroya, 1947) pueden extrapolarse a otras series episódicas con protagonista(s) fijo(s) de Bruguera y otras editoriales: "[...] cuentan siempre la misma historia modular con una pequeña serie de variaciones [...] todo en un 'tiempo intemporal' para los personajes y en un 'tiempo temporal' para las cosas y para las circunstancias" (1975: 148).

Varias décadas antes de las creaciones sobre las que escribía Ramírez, José Robledano demostraba con "El suero maravilloso" (Infancia, 1910) la flexibilidad entre estructuras seriales y episódicas propias de un sistema editorial que aún carece de las categorizaciones rígidas de una industria especializada. Así la mencionada creación de Robledano no solo supone un hito expresivo por su uso sistemático del bocadillo, sino que exhibe una interesante mutabilidad según los criterios de interés de su autor: comienza como serie de episodios hilados por unos protagonistas fijos y por la sustancia animadora de objetos que genera la pequeña trama de cada entrega; y se torna más adelante en relato serial, de desenlace suspendido, que deriva en una temática aventurera de tono humorístico (Martín, 1978: 45-48). El contraste entre la modernidad expresiva de esta obra de Robledano y el anquilosamiento de las historietas-folletines que se desarrollaban al mismo tiempo -e imperarían aún durante años- no oculta el hecho de 
que la aventura parece requerir un desarrollo que desborda la brevedad de la historieta corta. Tal vez deba buscarse la clave en el patrón profundo de esta clase de relato, reducible en la visión de Joseph Cambell a un monomito que consiste en el viaje del héroe y su superación de pruebas sucesivas hasta la consecución de una victoria final (Cambell, 2004: 28-37). Como quiera que pueda explicarse su afinidad con la serialidad, el hecho es que el primer atisbo de diversificación de sustancias de contenidos que se produce en la incipiente industria de la historieta más allá de lo cómico -y no es exclusivo del caso españolimplica el establecimiento de dos grandes macrogéneros, el humor y la aventura, cada uno de ellos asociado preferentemente con unas ciertas estructuras formales de los contenidos: la historieta singular o la serie episódica de personajes fijos en el caso del humor; y el serial de historietas en el caso de la aventura ${ }^{19}$.

La definición ulterior de estos perfiles hasta los primeros años treinta se produce en el marco de un sistema de fuerzas en el que la inercia de ciertos modos expresivos de las culturas gráficas y literarias españolas junto con las prácticas editoriales al uso coexisten con dos modelos de historieta en pugna, el europeo y el estadounidense. Lara (1996: 36) y Martín (1978: 52) coinciden en caracterizar el primero por la subordinación del dibujo al texto escrito como consecuencia de una concepción cultural reaccionaria, mientras que en el otro se integran con agilidad imágenes de diverso tipo, gracias al uso normalizado del bocadillo y al desarrollo de nuevos recursos expresivos. Ambos focos de influencia se hicieron notar durante décadas a través de los materiales importados, legalmente 0 no, reproducidos con calidad 0 calcados, hasta que las grandes revistas de los años treinta, hermanas de similares cabeceras italianas y francesas, sirvieron para el desembarco de una nueva generación de historietas llegadas de Estados Unidos. Su aspecto más innovador es el cultivo de temáticas genéricamente adscribibles a la aventura en combinación con un estilo de dibujo cuyo antepasado directo es la ilustración, como demuestran los dos máximos exponentes de esta nueva tendencia: Hal Foster y Alex Raymond. Con sus respectivas peculiaridades estilísticas, ambos dibujantes practican un realismo idealizado que se encontraba ausente de otras incursiones previas y contemporáneas en el terreno de la aventura20. De hecho, la serie que llegaría a conocerse como Hairbreadth Harry se remontaba a 1906 y en ella su creador, C. W. Kahles, había desarrollado para el cómic el triángulo arquetípico de héroe, villano y damisela en apuros, así como el final en suspensión por excelencia, el cliffhanger. Pero su dibujo no era realista, como tampoco lo eran en España los de Xaudaró y Robledano, ni lo serían en Estados Unidos los de series como Little Orphan Annie (Harold Gray, 1924), Thimble Theatre (E. C. Segar, 1919) y Wash Tubbs (Roy Crane, 1924), pese a contar con una importante vena aventurera, sobre todo a partir de las respectivas incorporaciones de los personajes Daddy Warbucks (1924), Popeye (1929) y Captain Easy (1929). En especial este último es sintomático del nuevo modo de visualizar la aventura, pues Easy, que se erige en héroe de acción, presenta una anatomía -junto con una caracterización física que influiría entre otros a Joe Shuster en su diseño facial de Superman-mucho más realista que la del personaje titular de la serie, cuyo origen se encontraba en el humor. No significaba esto que los registros estilísticos más cartoony quedasen proscritos para la aventura, pues la serie estadounidense Mickey Mouse (Walt Disney, Ub Iwerks y Win Smith, 1930) rápidamente dejó atrás la comicidad absoluta de sus raíces cinematográficas para introducirse por los senderos de la aventura, por más que el cliffhanger y el gag se alternaran e incluso se fundiesen en cada entrega. Sus equivalentes y casi coetáneos españoles pueden localizarse en obras de José Cabrero Arnal -creador de "Pif et Hercule" en su posterior exilio francés- como la historieta larga "Guerra en el país de los insectos" (Ediciones Pocholo, 1933), muy próxima en el tiempo a la primera aparición del insecto disneyano Bucky Bug (Silly Symphonies, Earl Duvall, 1932). En cuanto al realismo idealizado, probablemente los mejores ejemplos españoles sean Emilio Freixas y J esús Blasco, quienes produjeron algunas de las mejores muestras de esta tendencia desde la segunda mitad de los años treinta. Marcada también en sus inicios por autores como Riera Rojas o Jaime Tomás, el amplio y ambiguo espectro estilístico llamado realista se fijaría como el indicado por defecto para las historietas del igualmente amplio y ambiguo género de la aventura.

Como se adelantó más arriba, aparte de la asociación entre unas ciertas temáticas y unos determinados estilos de dibujo, la edición de cómics estadounidenses en España a mediados de los años treinta actuó como catalizador del progreso hacia un MRI del lenguaje historietístico. Es el resultado de una homogeneización de alcance internacional de las formas expresivas del cómic, vehiculada por el éxito y la distribución sistemática de estas historietas de 
prensa, merced a la organización industrial de los syndicates que las manejan. Martín describe del modo siguiente el advenimiento de esta normalización:

[...] bastará con que el cómic norteamericano se imponga en los quioscos para que el edificio editorial, hecho de prudencia, contenidos moralizantes refritos y pesadas historietas, se estremezca y vacile. No se derrumba, pero la tendencia es irreversible ya que el público lector y la competencia la imponen $y$, aunque se den muchos pasos atrás y adelante, la historieta española entra en una fase en la que las necesidades de mercado imponen a los editores su modernización (1978: 122).

La perturbación trágica a todos los niveles de la guerra civil hace dudar de esa reversibilidad al menos en sus consecuencias inmediatas sobre la producción de historietas durante la contienda, particularmente en el bando insurrecto, y después en muchas de las publicaciones de la primera posguerra, sobre todo en las que tienen periodicidad autorizada por sus lazos directos con el régimen franquista. En ese sentido, Lara ha leído en el retroceso del lenguaje de la historieta y el aferramiento a modelos expresivos obsoletos un síntoma de la ideología impuesta en aquel periodo: “En la España de la posguerra además, de forma especial y reivindicatoria, esta supervivencia de los densos paquetes tipográficos en el interior de las viñetas o fuera de ellas se presentaba como señal orgullosa y diferenciadora de lo autóctono, frente a lo americano" (1996: 36). No obstante, la tendencia ya había sido marcada y pronto comenzaron a retomarse los modos más modernos de hacer historieta, tanto desde algún excepcional tebeo protegido como Chicos, como desde las iniciativas comerciales que se enfrentaban a las duras condiciones de publicación con colecciones no declaradas de cabecera cambiante. Cuando, a finales de los años cuarenta, la situación se volvió algo más propicia y a principios de los cincuenta se concedieron permisos de publicación periódica con regularidad, editoriales como Bruguera, el grupo de Germán Plaza o en cierta medida la Editorial Valenciana tenían engrasadas sus maquinarias industriales para producir con relativa normalidad los contenidos que habían estado probando hasta entonces. El proceso de ensayo y error no cesaría mientras existiese una demanda masiva de historietas y así se consagrarían diversas fórmulas genéricas con sus correspondientes características del contenido y de las expresiones abstracta y material.

\section{Conclusiones: A MOdO DE 'CONTINUARÁ'}

Ya anunciaba al principio del presente artículo que no tenía la intención ni la capacidad para agotar el tema propuesto y que me conformaba con apuntar algunas ideas que pudieran servir para organizar su estudio en extensión y profundidad suficientes. Como parte de mi idea de relacionar acontecimientos, obras y autores por coincidencias temáticas, expresivas $y / 0$ culturales, he realizado saltos adelante y atrás en el tiempo, así como dentro y fuera de las fronteras estrictas del territorio nacional. No obstante, el centro de mi ensayo en el tercer bloque del artículo se ha encontrado aproximadamente en los primeros sesenta o setenta años de la historieta española, pues lo considero el periodo fundamental de gestación de un cierto sistema clásico de expresar a través de la historieta. Asimismo, en esas décadas se comienzan a definir ciertas categorías genéricas y sus correspondientes tratamientos gráficos, que serán refinados por la industria del tebeo de los años de la posguerra, para ser después madurados por algunos de los nuevos autores de los años sesenta y setenta, y radicalmente subvertidos por la línea chunga o cariñosamente comentados por la línea clara en los ochenta. De un modo u otro, salvo por la presencia sempiterna del humor en alguna de sus variantes, los géneros clásicos parecerían haberse diluido progresivamente en la producción nacional, ocupado ese lugar por las historietas importadas, mientras los historietistas españoles, en un país carente de tejido industrial para su medio, se entregaban a temáticas intimistas, autobiográficas, reivindicativas de la memoria histórica, sociales y, en general, más personales que comerciales, al amparo en tiempos recientes del ascendente formato de la novela gráfica. No obstante, estas redundancias temáticas acaban constituyendo ellas mismas nuevos géneros e incluso parece haberse producido una resurrección reciente de los géneros ortodoxos, tal vez por impregnación de las propiedades de que estos se han revestido en el actual panorama internacional completamente globalizado. Todos estos son puntos a desarrollar en la profundidad que merecen cuando la ocasión y la extensión así lo permitan, pero, en lo que al presente artículo respecta, mi propósito ha sido ofrecer algunas reflexiones sobre la aproximación al estudio histórico, algunas pautas teóricas para caracterizar el medio y arrojar tan solo una mirada al camino por el que el lenguaje y los contenidos de la historieta española dieron sus primeros pasos. 


\section{NOTAS}

1 Tanto en los títulos de obras como en las citas mantengo el criterio de cada autor en cuanto a tildar o no la castellanización del término inglés comic.

2 En Historia del cómic español: 18751939, indica como tal "Un drama desconocido", de autoría anónima y publicada en el número de enero de 1875 de la revista infantil Los Niños (M artín, 1978: 13-14); posteriormente, en Los inventores del cómic español 1873-1900, sitúa esa primera historieta española dos años antes, tratándose de "Por un coracero", obra de José Luis Pellicer, aparecida en EI Mundo Cómico, no 22, de marzo de 1873 (Martín, 2000b: 30-31).

3 En la edición original de Apuntes para una historia de los tebeos, seriada del no 194 al no 197 de Revista de Educación, entre 1967 y 1968.

4 Evidentemente, tanto el propio término "genealogía" como su sentido son deudores del modo en que los empleó Friedrich Nietzsche para titular su obra La genealogía de la moral (1887) y que fue retomado por Michel Foucault. Lo utilizo, sin embargo, en un sentido muy amplio y quiero evitar expresamente la alineación rigurosa con estos dos pensadores, pero sobre todo con quienes desde el ámbito postmoderno han querido trasladar la relativización de la verdad del terreno de lo histórico al de la teoría ahistórica o transhistórica, descartando también en esta la existencia de estructuras profundas e inmutables que son reflejo de nuestras propias estrategias cognitivas de procesado de la realidad.

Recibido: 14 de septiembre de 2010 Aceptado: 22 de noviembre de 2010
5 El texto clásico sobre su aplicación a la narrativa en la variedad de medios arriba mencionados se debe a Chatman (1978), si bien el modelo que yo propongo apuesta por segregar más radicalmente contenido de expresión, eliminando lo que considero ambigüedades a ese respecto en el reparto que hace este autor entre las formas de uno y otra. En especial, el modo en que define la forma de la expresión contradice la condición de especificidad del lenguaje del medio que estimo necesaria en el plano de la expresión: "Narrative discourse (the structure transmission) consisting of elements shared by narratives in any medium whatsoever" (1978: 24; el énfasis es mío).

6 "[...] mental models of who did what to and with whom, when, where, why, and in what fashion in the world to which recipients relocate -or make a deictic shift- as they work to comprehend a narrative" (2002: 9). En caso de no considerar la narración como una premisa fundamental del medio de la historieta - u otro, pues el plano del contenido es independiente del medio- podría considerarse el modelo mental en general, en lugar de la variedad narrativa que es el storyworld. Por otra parte, el recurso a la vertiente cognitivista del estudio narratológico abre una puerta a la consideración desde una perspectiva internalista de cuestiones pragmáticas como la inmersión narrativa, que difícilmente pueden tratarse desde el estructuralismo riguroso y que tan importantes han llegado a ser en la relación de los lectores con gran parte del cómic, tal como se ha desarrollado la cultura del medio.

7 Por ampliar el concepto de dibujo 0 pintura, para abarcar también la manipulación de fotografías u otras imágenes de procedencia indéxica. 
8 Por ejemplo, David Kunzle, al comienzo de su History of the Comic Strip (1973: 2) o Juan Antonio Ramírez, que aporta la siguiente definición de historieta en su Medios de masas e historia del arte: "un relato icónico-gráfico o iconográfico-literario destinado a la difusión masiva en copias mecánicas idénticas entre sí, sobre soporte plano y estático, y cuyos códigos (icónico y eventualmente literario) tienden a integrarse en sentido diegético-temporal" (1997: 198).

9 En The Art of the Funnies, Harvey distingue de cara a su análisis cuatro aspectos visuales de la historieta: el desglose narrativo (narrative breakdown), el diseño de página ( $p a-$ ge layout), la composición interna de la viñeta (panel composition) y el estilo (style) (1994: 14-15). En el manual Making Comics, McCloud considera que el historietista debe realizar cinco grandes elecciones ( $m o-$ ment, frame, image, word, flow), cada una de las cuales implica a su vez muchas otras opciones (2006: 10-36).

10 Son muchos los historietistas que dibujan sus propios guiones $y$, al principio, ni siquiera existía la figura del guionista de historietas, pues, si el dibujo de historietas tardó en concretarse como actividad profesional distinta, aún tardó más en hacerlo la guionización. Solo se comenzó a emplear a guionistas a partir de la serialización de historietas largas, que exigían un cierto sostén de contenidos $y$, aun así, aquellos primeros autores de guiones solían ser "periodistas, novelistas populares y escritores de segunda o tercera fila [...] siguiendo el dictado editorial y pensando más en la creación de novelitas cortas que de guiones específicos de historietas" (Martín, 1978: 70).

11 Como en el caso de Manuel Vázquez transmitido por José Peñarroya: "Yo le he visto hacer una historieta sin guión, sobre la marcha, y terminarla bien en la última viñeta" (Ramírez, 1997: 195).

12 Es evidente que si no se acota, exigiendo unos mínimos de distintos sistemas de significación, el modelo conduce a un continuo en alguno de cuyos extremos se encontraría, por ejemplo, el texto exclusivamente escrito.

13 Ensayo publicado originalmente en 1945 y recogido en Qu'est-ce que le cinéma? (1958).

14 A través de la incorporación y el perfeccionamiento del sonido, del color, de la tridimensionalidad; los experimentos con sentidos distintos de la vista y el oido (el Smell-0-Vision y su parodia, el Odorama; los trucos mecánicos ideados por William Castle, etc.); los intentos por sumergir al espectador en la ilusión fílmica (el sonido estéreo; los formatos panorámicos; el Omnimax; y las posibilidades de la realidad virtual)...

15 Me remito a la selección de obras que componen el grueso del volumen Los inventores del cómic español 1873/1900.

16 En su estudio del humor gráfico durante el franquismo, Iván Tubau (1987: 99-108) distingue dos grandes familias con sus respectivas subcategorías: el humor puro o evasivo (abstracto; absurdo y surrealista; poético; y negro) y el humor crítico (costumbrismo; crítica sociológico-moral; político y politizado). La clasificación es aplicable a periodos anteriores y posteriores a la dictadura de Franco.

17 A este respecto, véanse, por ejemplo, las conclusiones -extrapolables en buena medida- del estudio de las series televisivas por Sonia Livingstone (1990).

18 En 1927 Bluma Zeigarnik estableció que una tarea interrumpida deja una huella más intensa en la memoria que otra inconclusa (Zeigarnik, 2001).

19 Existen, no obstante, excepciones a esta regla. Durante lo que podría considerarse la edad dorada del tebeo español -por más que tal denominación resulte paradójica, dado el marco general de miseria en que se desarrolla - entre los últimos años cuarenta y los primeros sesenta, el formato por excelencia para la publicación de las historietas de aventureros es el cuaderno apaisado de pocas páginas en blanco y negro, heredero depauperado de similares inventos anteriores a la guerra civil. Entre sus ejemplos más destacados podríamos señalar las colecciones protagonizadas respectivamente por Roberto Alcázar y Pedrín (Juan Puerto y Eduardo Vañó, 1940) y por el Guerrero del Antifaz (Manuel Gago, 1943), ambas publicadas por Editorial Valenciana. Cada una se estructura de manera distinta en cuanto a la completitud del relato que constituye cada entrega y a la relación entre entregas sucesivas: la primera presenta una estructura episódica con personajes fijos, de modo tal que cada uno de los cuadernillos ofrece una aventura completa; por su parte, los cuadernos del Guerrero del Antifaz se acogen a la serialidad, culminando cada entrega en un final de "continuará", pero sin que haya final total previsto a la vista, dado que la serie se prolongaría tanto como hubiera un público dispuesto a comprarla.

20 En cierto modo, estos autores conectan la historieta con el afán barroco por embellecer la realidad a que se hacía referencia más arriba. 


\section{BIBLIOGRAFÍA}

Barrero, Manuel (2004): "El bilbaíno Víctor Patricio de Landaluze, pionero del cómic español en Cuba", en Mundaiz, no 68, julio, 53-79.

Bazin, André (1990): Qu'est-ce que le cinéma? París: Éditions du Cerf.

BozAL, Valeriano (1989): El siglo de los caricaturistas. Madrid: Grupo 16, Historia 16- Historia del Arte no 40.

BURCH, Noel (1991): El tragaluz del infinito (Contribución a la genealogía del lenguaje Cinematográfico. Madrid: Cátedra.

Cambell, Joseph (2004): The Hero with a Thousand Faces. Princeton: Princeton University Press.

Eco, Umberto (1997): Apocalípticos e integrados. Barcelona: Editorial Lumen.

GARCíA, Santiago (2010): La novela gráfica. Bilbao: Astiberri.

GROUPE İ (1993): Tratado del signo visual Madrid: Cátedra.

HARVEY, Robert C. (1994): The Art of the Funnies: an Aesthetic History. Jackson: The University Press of Mississippi.

Herman, David (2002): Story Logic: Problems and Possibilities of Narrative. Lincoln: University of Nebraska Press.
HJelmSLev, Louis (1961): Prolegomena to a Theory of Language. Madison: University of Wisconsin Press.

KunzlE, David (1973): The Early Comic Strip; Narrative Strips and Picture Stories in the European Broadsheet from c. 1450 to 1825. Berkeley: University of California Press.

Lara, Antonio (1996): "Tebeos: los primeros 100 años. 1896-1974", en VV AA, Tebeos: los primeros 100 años. Madrid: Biblioteca Nacional y Grupo Anaya, 29-130.

LIVINGSTONE, Sonia (1998): Making Sense of Television: The Psychology of Audience Interpretation. Londres: Routledge.

LlerA, José Antonio (2007): "Ni pobre ni rico, sino todo lo contrario de Mihura y Tono (La paradoja del 'humor nuevo')", en García BarrienTOS, José Luis (dir.), Análisis de la Dramaturgia. Nueve obras y un método. Madrid: Fundamentos, 313337.

Martín, Antonio (1978): Historia del cómic español: 1875-1939. Barcelona: Gustavo Gili.

- (2000a): Apuntes para una historia de los tebeos. Barcelona: Glénat.
- (2000b): Los inventores del comic español 1873-1900. Barcelona: Planeta-DeAgostini.

M CCLoud, Scott (2006): Making Comics: Storytelling Secrets of Comics, Manga and Graphic Novels. Nueva York: Harper.

RAmíREZ, Juan Antonio (1997): La historieta cómica de posguerra. Madrid: Cuadernos para el Diálogo.

- (1997): Medios de masas e historia del arte. Madrid: Cátedra.

Remesar, Antoni (1984): Xaudaró. El reto de la aventura (1897/1903). BarceIona: Editorial Complot.

Suls, J. M. (1972): "A Two-Stage Model for the Appreciation of Jokes and Cartoons: An InformationProcessing Analysis", en GoLdSTEIN, J. H. y. McGhee, P. E (eds.), The psychology of humor: Theoretical perspectives and empirical issues. Nueva York: Academic Press, 81100.

TUBAU, Iván (1987): El humor gráfico en la prensa del franquismo. Barcelona: Mitre.

ZeIGARNIK, B. V. (2001): "On Finished and Unfinished Tasks", en Elus, W. D. (ed.), A Sourcebook of Gestalt Ps. 